\title{
Purification and Biochemical Characterization of Polygalacturonase Produced by Penicillium expansum During Postharvest Decay of 'Anjou' Pear
}

\author{
Wayne M. Jurick II, Ivana Vico, Verneta L. Gaskins, Wesley M. Garrett, \\ Bruce D. Whitaker, Wojciech J. Janisiewicz, and William S. Conway
}

First, third, fifth, and seventh authors: Food Quality Laboratory, U.S. Department of Agriculture-Agricultural Research Service (USDAARS), BARC-West, Beltsville, MD; second author: Institute of Phytomedicine, Faculty of Agriculture, University of Belgrade, Serbia; fourth author: Animal Biosciences and Biotechnology Lab, USDA-ARS, BARC-East, Beltsville, MD; and sixth author: Appalachian Fruit Research Station, USDA-ARS, Kearneysville, WV.

Accepted for publication 9 September 2009.

\begin{abstract}
Jurick, W. M., II, Vico, I., Gaskins, V. L., Garrett, W. M., Whitaker, B. D., Janisiewicz, W. J., and Conway, W. S. 2010. Purification and biochemical characterization of polygalacturonase produced by Penicillium expansum during postharvest decay of 'Anjou' pear. Phytopathology 100:42-48.

A polygalacturonase $(\mathrm{PG})$ was extracted and purified from decayed tissue of 'Anjou' pear fruit inoculated with Penicillium expansum. Ammonium sulfate precipitation, gel filtration, and cation exchange chromatography were used to purify the enzyme. Both chromatographic methods revealed a single peak corresponding to PG activity. PG enzyme activity from healthy and wounded pear tissue was undetectable, which

active over a broad $\mathrm{pH}$ range from 3 to 6 , with optimal activity at 4.5 in sodium citrate and sodium acetate buffers. The optimal temperature for activity was $37^{\circ} \mathrm{C}$ but the enzyme was also active at $0,5,10,20$, and $50^{\circ} \mathrm{C}$. Thin-layer chromatographic analysis of PG hydrolysis products showed that the enzyme exhibits endo- and exo-activity. The purified enzyme macerated tissue in vitro causing $\approx 30 \%$ reduction in mass of pear plugs compared with $\approx 17 \%$ reduction for apple. Additionally, it produced 1.5 -fold more soluble polyuronides on pear than apple tissue. This work shows for the first time the production of a PG by $P$. expansum during postharvest decay of pear fruit is different from the previously described PG produced in decayed apple fruit by the same pathogen.
\end{abstract} supports the claim that the purified PG is of fungal origin. The purified enzyme had a molecular mass of $41 \mathrm{kDa}$ and a pI of 7.8. Activity of the PG was not associated with a glycosylated protein. The enzyme was

Additional keywords: host specificity, maceration.

Penicillium expansum (Link) Thom., the causal agent of blue mold, is the most important postharvest pathogen of pome fruits $(16,19,21)$. This pathogen infects fruit through wounds after harvest, as well as through natural openings, i.e., lenticel, stem end, and calyx (19). Blue mold is characterized by a soft, watery rot that is light brown in color, and the appearance of blue-green colored conidia on the surface at the later stages of decay development (7). Blue mold decay can lead to significant economic losses during storage, which can also impact fruit destined for processing due to the production of the carcinogenic mycotoxin patulin. Chemical control of blue mold is achieved through application of fungicides like fludioxonil and thiabendazole. However, increased use of these compounds often leads to resistance which reduces their efficacy. Therefore, a better understanding of the mechanisms of blue mold fruit rot may provide information for the development of novel innovative control strategies for this disease.

The plant cell wall serves as the major physiochemical barrier to the establishment of plant pathogens, and is composed of four major complex polysaccharides (cellulose, hemicellulose, lignin, and pectin) (25). Pectin is the major component of the middle lamella, which causes adhesion of adjacent primary cell walls in dicots and nongraminaceous monocots. In addition, pectin is

Corresponding author: W. M. Jurick, II; E-mail address: Wayne.Jurick@ars.usda.gov

doi:10.1094/PHYTO-100-1-0042

This article is in the public domain and not copyrightable. It may be freely reprinted with customary crediting of the source. The American Phytopathological Society, 2010. complexed with hemicellulose and cellulose microfibrils, provides cell wall integrity, is a critical component for plant tissue organization, and adds texture to fruits and vegetables (17). Pectin is a polymer of D-galacturonic acid linked by $\beta$-1,4-glycosidic bonds, which are cross-linked by carboxyl groups with divalent cations such as $\mathrm{Ca}$ and $\mathrm{Mg}(10)$.

Polygalacturonases (PGs) (EC 3.2.1.15) are produced by bacterial and fungal plant pathogens to hydrolyze pectins and thereby facilitate the invasion and colonization of host tissue. PGs cleave the $\beta-1,4$-glycosidic bond between adjacent polygalacturonic acid residues by a single displacement mechanism (15). They are detectable in the initial stages of plant infection and produced in copious amounts during host colonization (6). PGs have been associated with diseases characterized by tissue maceration and soft rot $(2,3)$. Genetic evidence that PG contributes significantly to virulence has been achieved via analyses of PG genes in Botrytis cinerea (Bcpgl gene) and in Aspergillus flavus ( $P 2 c$ gene) $(8,23)$. PGs are also produced by plants, and in pear have been shown to be involved in fruit ripening and softening via degradation of cortical cell walls $(9,22)$.

PGs play a significant role in tissue maceration, colonization, and virulence. However, it is not known if different PGs are produced in different hosts during postharvest decay. $P$. expansum produces at least five PG enzymes in culture (C. L. Yao, unpublished data). However, only one PG has previously been isolated from $P$. expansum-decayed apple fruit (26). Therefore, the objectives of this study were (i) to isolate and purify PG from $P$. expansum-decayed pear fruit, (ii) to biochemically characterize the purified PG, (iii) to determine if the purified enzyme was 
capable of macerating pear and apple fruit tissue in vitro, (iv) and to compare biochemical characteristics between PGs produced in apple and pear fruit by the same isolate of $P$. expansum. Data from this study indicates that $\mathrm{PG}$ produced by $P$. expansum in decayed pear fruit can function over a broad $\mathrm{pH}$ and temperature range, can macerate pear and apple fruit tissue in vitro, and is different from the PG produced by this pathogen during apple fruit decay.

\section{MATERIALS AND METHODS}

Fruit, pathogen and chemicals. Mature 'Anjou' pear fruit were purchased from a local grocery store in Beltsville, MD. The $P$. expansum isolate used in this study is the same one described by Yao et al. (26), which was isolated from naturally infected apple fruit and maintained on potato dextrose agar. All chemicals used in this work were purchased from Sigma Chemical Co. (St. Louis, MO) unless indicated otherwise.

Pear fruit inoculation and enzyme extraction. Pear fruit was washed with soap and water, sprayed with $70 \%$ ethanol, and dried with a paper towel. Pears were then subjected to the following treatments: wound inoculation with $50 \mu \mathrm{l}$ of conidial spore suspension of $P$. expansum $\left(10^{5}\right.$ conidia/ml $)$ as previously described (5); wound inoculation with $50 \mu \mathrm{l}$ of sterile water; and addition of $50 \mu \mathrm{l}$ of sterile water on the fruit surface of unwounded healthy pears. After 14 days of storage at $24^{\circ} \mathrm{C}$, the peel over the lesion was removed and the decayed cortical tissue was collected for enzyme extraction. Decayed tissue was weighed and an equal amount of tissue was also harvested from the healthy intact and wounded pears. The fruit tissue was added to an equal volume of $20 \mathrm{mM} 2-[N$-morpholino] ethanesulfonic acid (MES) with $1 \mathrm{M}$ sodium chloride ( $\mathrm{pH}$ 6.0), and stirred for 30 min followed by filtering through Miracloth (Calbiochem-Behring, La Jolla, CA). The filtrates from each sample (decayed, healthy intact, and wounded) were centrifuged at $20,000 \times g$ for $30 \mathrm{~min}$ and ammonium sulfate was added to the supernatant to $40 \%$ saturation while stirring. Once the ammonium sulfate dissolved, the mixtures were centrifuged for $30 \mathrm{~min}$ at $20,000 \times \mathrm{g}$. Ammonium sulfate was again added to the supernatants to obtain $90 \%$ saturation. These mixtures were then centrifuged for $30 \mathrm{~min}$ at $20,000 \times g$ and the supernatants were discarded. The pellets were dissolved in $20 \mathrm{mM}$ MES with $0.15 \mathrm{M}$ sodium chloride ( $\mathrm{pH}$ 6.0) and stored at $4^{\circ} \mathrm{C}$. All extraction and purification procedures were carried out at $4^{\circ} \mathrm{C}$.

Enzyme purification. Approximately $5 \mathrm{ml}$ of the dissolved $90 \%$ ammonium sulfate pellet was loaded onto a Sephacryl S-200 column $(2.5 \times 52 \mathrm{~cm})$ that was equilibrated with $20 \mathrm{mM}$ MES in $0.15 \mathrm{M}$ sodium chloride ( $\mathrm{pH}$ 6.0). PG was eluted using the above buffer at $30 \mathrm{ml} / \mathrm{h}$ and $604-\mathrm{ml}$ fractions were collected. Following elution, gel filtration fractions from decayed tissue exhibiting PG activity were pooled and dialyzed overnight against $20 \mathrm{mM}$ MES (pH 6.0). PG was further fractionated on a CM-Sephadex column (Pharmacia C-25 cation exchange) equilibrated with $20 \mathrm{mM}$ MES, pH 6.0. The solution was placed on the column $(1.6 \times$ $9.8 \mathrm{~cm})$ and was eluted with a linear gradient $(30 \mathrm{ml} / \mathrm{h})$ of $20 \mathrm{mM}$ MES to $20 \mathrm{mM}$ MES with $1 \mathrm{M} \mathrm{NaCl}$ (pH 6.0). Thirty 4-ml fractions were collected and stored at $4^{\circ} \mathrm{C}$ for further analysis.

Reducing sugar assay for PG activity. PG activity was determined by measuring reducing sugars released from sodium polypectate, using D-galacturonic acid as the standard as described by Yao et al. (26). An aliquot of the enzyme preparation was mixed with $0.1 \mathrm{ml}$ of assay buffer (100 mM sodium acetate, $\mathrm{pH} 5.5$, containing $0.4 \%$ polygalacturonic acid) and adjusted to a final volume of $0.2 \mathrm{ml}$ with water in borosilicate tubes $(13 \times 100 \mathrm{~mm})$. This mixture was incubated at $37^{\circ} \mathrm{C}$ for $20 \mathrm{~min}$ and $1 \mathrm{ml}$ of $100 \mathrm{mM}$ borate-borax buffer $(\mathrm{pH} 9.0)$ was added to stop the reaction. Solutions of $0.1 \%$ 2-cyanoacetamide $(0.2 \mathrm{ml})$ were added and samples were placed into a boiling water bath for
$10 \mathrm{~min}$. Samples were then equilibrated to $20^{\circ} \mathrm{C}$ and absorbance at $276 \mathrm{~nm}$ was measured. Control reactions were carried out by adding borate-borax buffer with 2-cyanoacetamide prior to the addition of substrate buffer and were assayed for each sample to determine background levels of reducing sugars. One unit of PG activity was defined as the amount of enzyme required to release 1 nanomole of reducing sugar per minute per milliliter under the assay conditions employed.

Plate assay for PG activity. PG activity was determined by a modified method previously described by Saad et al. (20). A $1 \%$ (wt/vol) agarose solution was heated until dissolved. A $0.1 \%$ solution of sodium polypectate was added to the agarose solution and adjusted to $\mathrm{pH} 5.5$ with $1 \mathrm{~N} \mathrm{NaOH}$ solution while stirring. Then, $15 \mathrm{ml}$ of the agarose solution was poured into petri dishes $(100 \times 15 \mathrm{~mm})$ and allowed to cool. Four wells were punched in the agarose using a cork borer ( $2 \mathrm{~mm}$ diameter) and solutions were pipetted into each of the wells. The plates were incubated at $37^{\circ} \mathrm{C}$ for $14 \mathrm{~h}$ before incubating with $0.05 \%$ (wt/vol) ruthenium red (Acros) for $1 \mathrm{~h}$ at $20^{\circ} \mathrm{C}$. Plates were destained with deionized water for $30 \mathrm{~min}$ and visualized on a light box.

Sodium dodecyl sulfate-polyacrylamide gel electrophoresis. Sodium dodecyl sulfate-polyacrylamide gel electrophoresis (SDSPAGE) of proteins was performed in a Bio-Rad Mini-protean III cell using a precast $12 \%$ gel according to Leammli (12). The molecular mass of the protein was estimated using Protein Plus Precision Standards (Bio-Rad Laboratories, Hercules, CA). Protein bands were visualized using Bio-Safe Coomassie stain (BioRad Laboratories) according to the manufacturer's protocol.

Isoelectric focusing-polyacrylamide gel electrophoresis. Isoelectric focusing-polyacrylamide gel electrophoresis (IEFPAGE) of purified PG was performed using a pre-cast Ampholine IEF gel (pH 3.5 to 9.5, GE Life Sciences) in a Pharmacia Biotech Multiphor II system following the manufacturer's instructions (Amersham-Pharmacia). The electrode strips were soaked with $1 \mathrm{M}$ phosphoric acid (anode) and $1 \mathrm{M}$ sodium hydroxide (cathode) and were placed on opposing sides of the gel. Protein

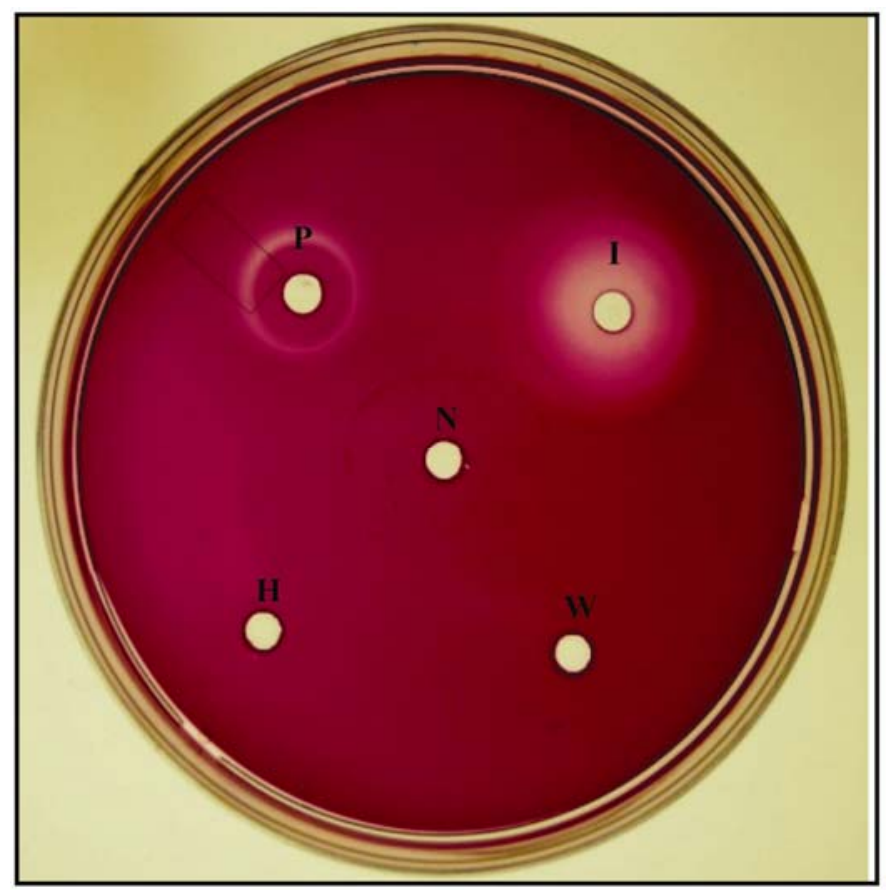

Fig. 1. Polygalacturonase plate assay of $90 \%$ ammonium sulfate pellets from intact healthy $(\mathrm{H})$, wounded healthy $(\mathrm{W})$, and Penicillium expansum-decayed 'Anjou' pear fruit (I). The negative control (N) contained $20 \mathrm{mM}$ MES + $0.15 \mathrm{M}$ sodium chloride $(\mathrm{pH}$ 6.0). The positive control $(\mathrm{P})$ contained a commercial preparation of pectinase obtained from Aspergillus niger. The experiment was repeated and a representative plate is shown. 
samples were applied to application strips that were then placed directly on the gel. IEF protein standards (pI range 3.5 to 10.7, SERVA) were diluted 1:5 with water prior to loading. Isoelectric focusing was then conducted at $1,500 \mathrm{v}, 25 \mathrm{ma}, 25 \mathrm{w}$ for $1.5 \mathrm{~h}$. The gel was stained with silver using the SilverQuest staining kit (Invitrogen) according to the manufacturer's instructions.

Glycosylation analysis. A Qproteome total glycoprotein isolation kit, containing lectin affinity spin columns, was purchased from Qiagen. Purified PG (1.2 U) was fractionated according to the manufacturer's protocol. Fractions eluted from the column; flow through, wash, mannose elution and sialic acid elution were collected and concentrated by acetone precipitation and analyzed for activity using the PG plate activity assay. A well characterized glycoprotein (Ribonuclease b) was purchased from Sigma and served as a positive control for the lectin columns. Fractions from the positive control were concentrated by acetone precipitation and analyzed by SDS-PAGE. Protein bands were visualized using Bio-Safe Coomassie stain (Bio-Rad Laboratories) according to the instructions provided.

Temperature optima. The optimal temperature for PG enzyme activity was determined using the reducing sugar assay by incubating $1.2 \mathrm{U}$ of purified PG with $100 \mathrm{mM}$ sodium acetate buffer, $\mathrm{pH} 5.5$, in borosilicate tubes $(13 \times 100 \mathrm{~mm})$ placed in water baths at $0,5,10,20,37,50$, and $75^{\circ} \mathrm{C}$ for $20 \mathrm{~min}$. Assays for each temperature were conducted in triplicate and the experiment was repeated.

Thermal stability. Thermostability of the purified enzyme was determined by boiling aliquots of the enzyme (1.2 $\mathrm{U})$ over time $(0,5,10,15,20,25$, and $30 \mathrm{~min})$ and assaying activity in $100 \mathrm{mM}$ sodium acetate buffer $(\mathrm{pH} 4.5)$ at $37^{\circ} \mathrm{C}$. Reactions were conducted in triplicate and the experiment was repeated.

pH optima. To determine the optimal $\mathrm{pH}$ for PG activity, assays were performed in $100 \mathrm{mM}$ sodium acetate and $100 \mathrm{mM}$ sodium citrate with $0.4 \%$ polygalacturonic acid adjusted to a $\mathrm{pH}$ ranging from 3.0 to 7.0 in $0.5 \mathrm{pH}$ increments as described (26,27). Reactions were conducted in triplicate and the experiment was repeated.

Analysis of PG hydrolysis products by thin-layer chromatography. Purified PG (6 U) was used to determine the hydrolysis products of polygalacturonic acid after incubation in $100 \mathrm{mM}$ sodium acetate buffer $(\mathrm{pH} 4.5)$ for $0,5,10,15,20,25,30$, and $60 \mathrm{~min}$ and $24 \mathrm{~h} \mathrm{at} 37^{\circ} \mathrm{C}$. From the $0.5 \mathrm{ml}$ reaction volume, a $50 \mu \mathrm{l}$ aliquot was removed at each time interval and heated at $100^{\circ} \mathrm{C}$ for $30 \mathrm{~min}$. After boiling, the samples were immediately placed at $-80^{\circ} \mathrm{C}$ until analyzed. Thawed samples were then nitrogen-evaporated to dryness and resuspended in $20 \mu \mathrm{l}$ of $50 \%$ ethanol. A five-microliter aliquot from each time point was separated on a $10 \times 20 \mathrm{~cm}$ glass thin-layer chromatography (TLC) plate precoated with $250 \mu \mathrm{m}$ thick silica gel 60 (EM Science, Darmstadt, Germany). The monomer, dimer, and trimer of galacturonic acid were used as standards. The TLC plate was developed in the ethyl acetate: acetic acid: formic acid: water, 9:3:1:4 ( $\mathrm{vol} / \mathrm{vol} / \mathrm{vol} / \mathrm{vol}$ ) solvent system. After development, the plates were air dried in a fume hood for $12 \mathrm{~h}$ and sprayed with orcinol reagent $(0.2 \%$ orcinol [wt/vol] in methanol/sulfuric acid, 9:1 [vol/vol]). The plate was then placed on a hotplate at medium high heat for $3 \mathrm{~min}$ to visualize the galacturonic acids.

TABLE 1. Purity and activity of the purified polygalacturonase from 'Anjou' pear fruit decayed by Penicillium expansum at various stages of enzyme purification $^{\mathrm{a}}$

\begin{tabular}{lccc}
\hline Step & $\begin{array}{c}\text { Total activity } \\
(\mathrm{U} / \mathrm{min} / \mathrm{ml})\end{array}$ & $\begin{array}{c}\text { Protein } \\
(\mathrm{mg} / \mathrm{ml})\end{array}$ & $\begin{array}{c}\text { Specific activity } \\
(\mathrm{U} / \mathrm{mg})\end{array}$ \\
\hline 90\% pellet & 137.0 & 25.6 & 5.36 \\
Gel filtration & 27.9 & 0.22 & 127 \\
Dialysis & 15.8 & 0.20 & 79 \\
Cation exchange & 128.6 & 0.01 & 12,860 \\
\hline
\end{tabular}

a Values represent the means from samples assayed in triplicate.
Fruit tissue maceration assay. Pear fruit were removed from cold storage $\left(1.4^{\circ} \mathrm{C}\right)$ and set out on a laboratory bench top at $20^{\circ} \mathrm{C}$ for $1 \mathrm{~h}$. The fruit were then rinsed with soap and water, sprayed with $70 \%$ ethanol, and dried with a paper towel. Wounds $(3 \times$ $3 \mathrm{~mm}$ ) were made in the fruit using a nail embedded in a piece of cork, and $50 \mu \mathrm{l}$ of sterile water or $5 \mathrm{U}$ of PG enzyme were added to each wound. Pear fruit were kept at $37^{\circ} \mathrm{C}$ for $24 \mathrm{~h}$ after which tissue maceration was evaluated by slicing through the wound with a scalpel. For in vitro tissue maceration tests both pear and 'Golden Delicious' apple fruit were removed directly from $1.4^{\circ} \mathrm{C}$ and rinsed with soap and water. The fruit were then sprayed with $70 \%$ ethanol and wiped dry. A sterilized hand held vegetable peeler was used to aseptically remove the peel from the fruit. Apple and pear tissue plugs were collected from the peeled area using a No. 2 cork borer. All plugs were trimmed to $1 \mathrm{~cm}$ in length using a sterile scalpel. Each plug was then placed into $50 \mathrm{ml}$ of $100 \mathrm{mM} \mathrm{Na}$-acetate buffer $\mathrm{pH} 4.5$ in a beaker and incubated for $1 \mathrm{~h}$ at $37^{\circ} \mathrm{C}$. The plugs were then removed from the beakers, blotted for $5 \mathrm{~s}$ and the initial weight (0 time) was recorded. One tissue plug was placed into each borosilicate tube $(13 \times 100 \mathrm{~mm})$ and $2 \mathrm{ml}$ of Na-acetate buffer, $\mathrm{pH} 4.5$, was added. Then, either $12.8 \mu \mathrm{l}$ of buffer, $\mathrm{pH} 4.5,12.8 \mu \mathrm{l}(1.2 \mathrm{U})$ of denatured PG, or $12.8 \mu \mathrm{l}(1.2 \mathrm{U})$ of native PG enzyme was added to each tube. The samples were then incubated at $37^{\circ} \mathrm{C}$ for $48 \mathrm{~h}$. The plugs were removed from each tube, blotted on tissue paper for $5 \mathrm{~s}$ and the weight was recorded. Tissue plugs were then discarded and the remaining buffer in the tubes was placed at $4{ }^{\circ} \mathrm{C}$ for future analysis of total soluble polyuronides.

Total soluble polyuronide assay. Total soluble polyuronides were determined according to the method previously described (4). Briefly, $100 \mu \mathrm{l}$ of buffer sample from each maceration assay was removed and placed in microfuge tubes. Tubes were then vortexed briefly and centrifuged at $14,000 \times g$ for $1 \mathrm{~min}$. Ten microliters of the pooled buffer solution was added to $90 \mu \mathrm{l}$ of water in a borosilicate tube $(13 \times 100 \mathrm{~mm})$ and briefly vortexed to mix. Samples were placed in an ice bath and $600 \mu \mathrm{l}$ of sulfuric acid tetra borate solution $(12.5 \mathrm{mM}$ tetra borate in concentrated sulfuric acid) was added. All samples were vortexed briefly and placed in a boiling water bath at $100^{\circ} \mathrm{C}$ for $5 \mathrm{~min}$. Samples were then cooled immediately on ice to room temperature and $10 \mu \mathrm{l}$ of m-phenylphenol reagent $(0.15 \% \mathrm{~m}$-phenylphenol in $0.5 \%$ sodium hydroxide) was added and mixed by vortexing. Absorbance $(520 \mathrm{~nm})$ of the samples was determined using a spectrophotometer (SmartSpec, Bio-Rad Laboratories). Concentration of polyuronides in buffer solutions from the maceration assay was determined according to a standard curve developed for galacturonic acid. All samples were assayed in triplicate and the experiment was repeated.

\section{RESULTS}

Purification of PG produced by $P$. expansum in decayed pear fruit. $P G$ produced by $P$. expansum during pear fruit colonization was purified using a multistep process. For each step, total protein decreased and specific activity increased (Table 1). The source of PG activity in $P$. expansum-pear fruit tissue is fungal in origin as evidenced by the clear zone from the $90 \%$ ammonium sulfate pellet collected from infected material and lack of a clear zone from both intact and wounded healthy tissue using 90\% ammonium sulfate pellets (Fig. 1). Other protein fractions from healthy and wounded pear fruit including: crude extract, $40 \%$ ammonium sulfate pellet and supernatant, and 90\% ammonium sulfate pellet and supernatant had undetectable PG activity using the reducing sugar assay (data not shown).

Biochemical characterization of $P$. expansum PG. Single peaks, corresponding to $\mathrm{PG}$ activity, were detectable for both gel filtration and cation exchange chromatography (Fig. 2A and B). SDS-PAGE analysis of the cation exchange purified material 
revealed a single band of approximately $41 \mathrm{kDa}$ (Fig. 3A). A pI of 7.8 for the purified PG was determined by analytical isoelectric focusing (Fig. 3B). Fractionation of the enzyme using a glycoprotein affinity column showed that PG activity was detected only in the flow through and wash fractions and was undetectable in the mannose and sialic acid buffer elution steps (Fig. 4). Optimal reaction temperature was determined to be $37^{\circ} \mathrm{C}$. However, PG activity was also detectable at $0,5,10,20$, and $50^{\circ} \mathrm{C}$ (Fig. 5A) The PG was active over a broad $\mathrm{pH}$ range from 3 to 6 with the optimum at $\mathrm{pH} 4.5$ in both buffer systems (Fig. 5B). The purified enzyme was heat labile as boiling for $5 \mathrm{~min}$ reduced approximately $80 \%$ of PG activity (Fig. 5C). The PG hydrolyzed polygalacturonic acid in a mixed manner exhibiting both endo and exo activity according to TLC separation of enzymatic hydrolysis products (Fig. 6).

Maceration of pear and apple fruit tissue. PG purified from $P$. expansum-decayed pear fruit was added to wounds made in intact pear fruit to qualitatively evaluate its tissue macerating ability. After incubation at $37^{\circ} \mathrm{C}$ for $48 \mathrm{~h}$, both the diameter and depth of the wound increased. There were no visible changes in the wounded only and water only controls (data not shown). To quantitatively measure the maceration ability of purified PG, pear and apple tissue plugs were incubated with buffer alone and buffer with purified PG from $P$. expansum-decayed pear tissue. There was a difference in the decrease in fruit tissue weight that occurred in pear $(\approx 30 \%)$ compared with apple $(\approx 17 \%)$ samples after $48 \mathrm{~h}$ incubation (Fig. 7A). A change in texture and a slight change in color of the tissue were observed for the native PGtreated pear tissue, but not for apple tissue (data not shown).

A

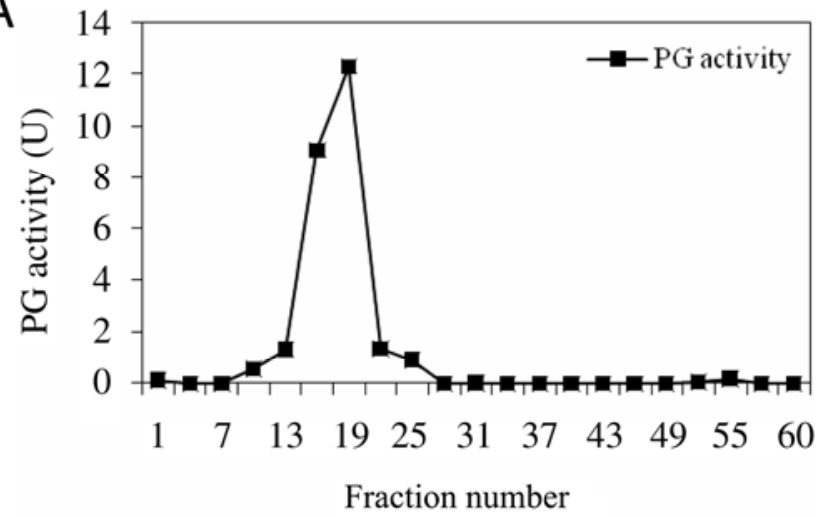

B

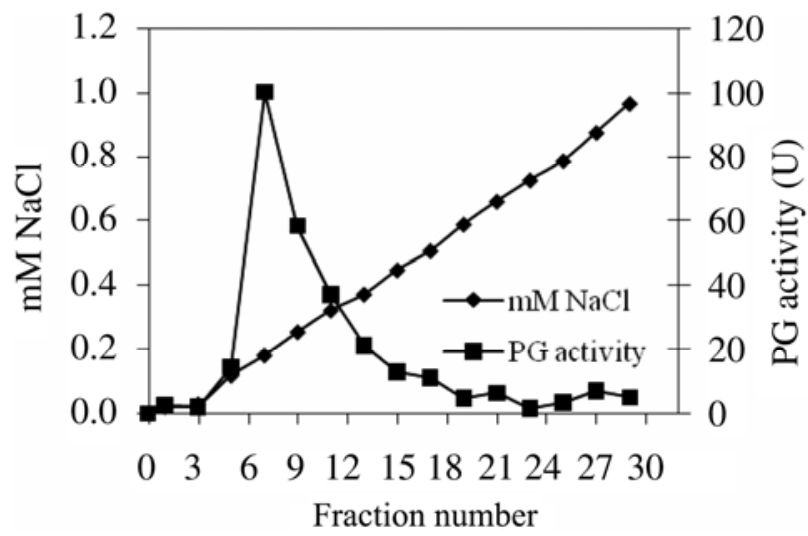

Fig. 2. A, Elution profile of a polygalacturonase (PG) produced by Penicillium expansum following fractionation on a Sephacryl S-200 gel filtration column. Proteins were eluted in $604-\mathrm{ml}$ fractions with $20 \mathrm{mM} 2$-[ $N$-morpholino]ethanesulfonic acid ( $\mathrm{pH}$ 6.0) with $150 \mathrm{mM} \mathrm{NaCl}$. B, PG activity in gradient elution of 10 pooled and dialyzed gel filtration peaks that were fractionated on a CM-Sephadex cation exchange column. Proteins were eluted in 30 4-ml fractions with a linear 0 to $1.0 \mathrm{M} \mathrm{NaCl}$ gradient in $20 \mathrm{mM}$ MES (pH 6.0).
Polyuronides from pear and apple fruit in vitro. Buffer solutions from macerated apple and pear tissue plugs were assayed for total soluble polyuronide content. Pear tissue incubated with the enzyme for $48 \mathrm{~h}$ at $37^{\circ} \mathrm{C}$ produced $32.6 \mu \mathrm{g}$ of soluble polyuronides compared with $22.3 \mu \mathrm{g}$ for apple fruit tissue. Basal levels of soluble polyuronides in control treatments containing pear or apple fruit tissue in buffer solutions without enzyme were 6.3 and $12 \mu \mathrm{g}$, respectively (Fig. 7B).

\section{DISCUSSION}

Multiple lines of biochemical evidence (MW, pI, and $\mathrm{pH}$ optima) suggest that the PG produced by $P$. expansum during apple decay is different from the PG produced during pear decay.
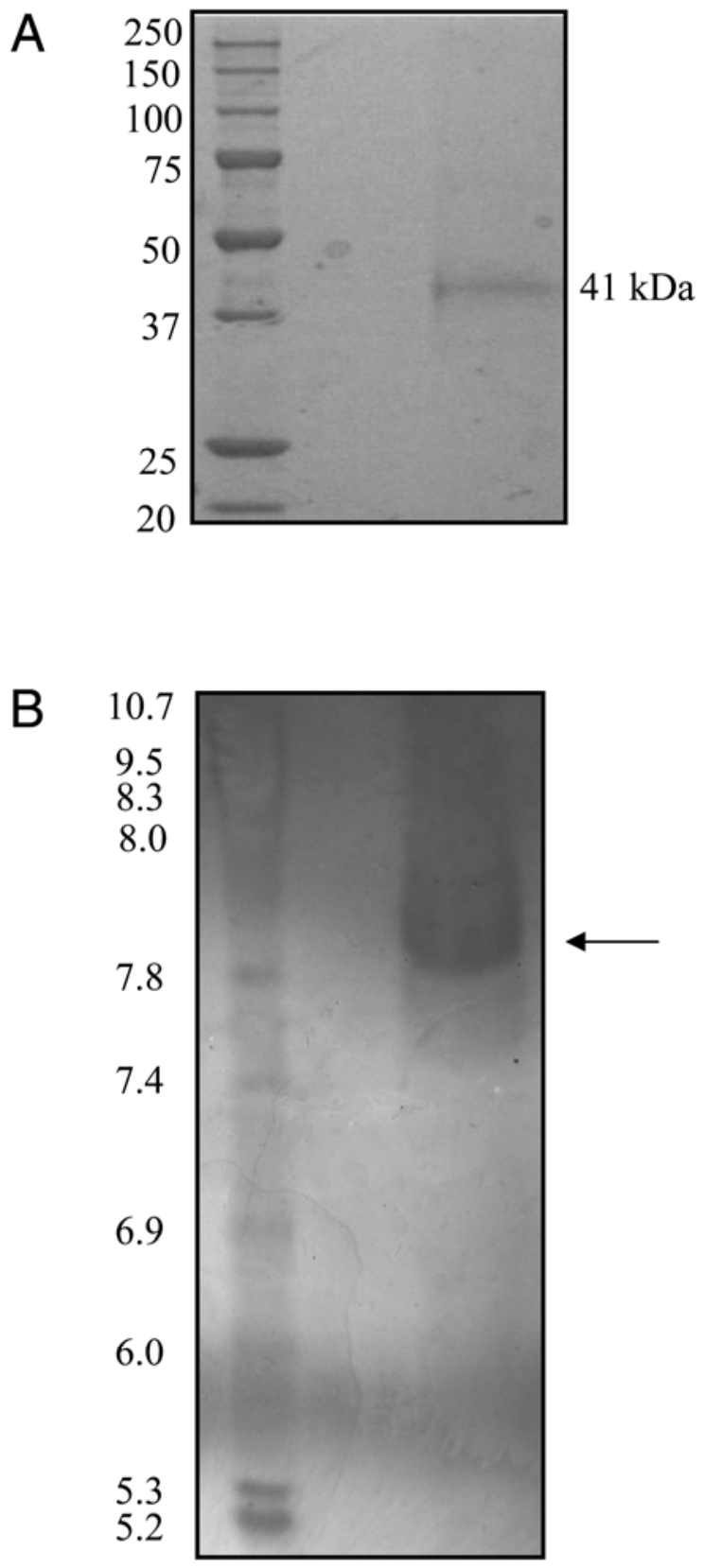

Fig. 3. A, Sodium dodecyl sulfate-polyacrylamide gel electrophoresis (12\%) of purified polygalacturonase produced by Penicillium expansum-decayed pear fruit that was stained with Coomassie blue. Sizes of molecular weight markers are indicated in $\mathrm{kDa}$. B, Isoelectric focusing polyacrylamide gel electrophoresis of purified polygalacturonase produced by $P$. expansum in decayed 'Anjou' pear fruit stained with silver. The pIs of standard proteins are indicated on the left. 


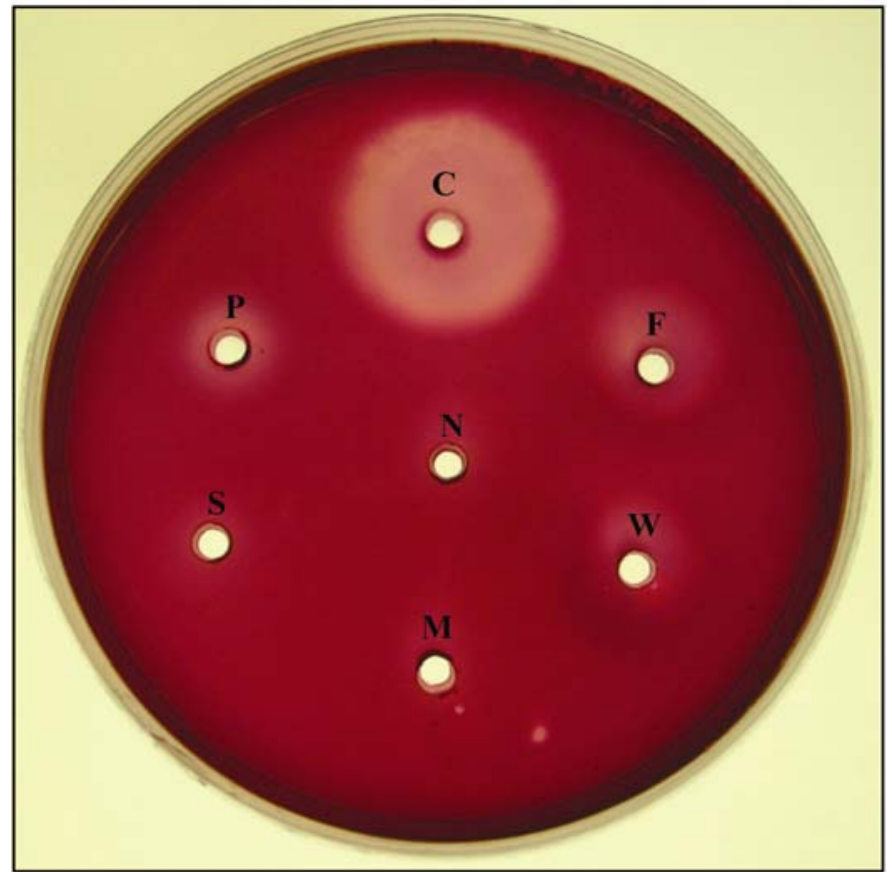

Fig. 4. Polygalacturonase plate activity assay of cation exchange-purified enzyme from Penicillium expansum-decayed 'Anjou' pear fruit following fractionation on a glycoprotein-binding column. The samples are represented as $\mathrm{C}=$ cation exchange purified polygalacturonase from $P$. expansum-decayed pear fruit; $\mathrm{F}=$ column flow through; $\mathrm{W}=$ column wash; $\mathrm{M}=$ mannose elution step; $\mathrm{S}=$ sialic acid elution step; $\mathrm{P}=$ pectinase from Aspergillus niger , and $\mathrm{N}=$ water.

The molecular mass of the protein is consistent with reports for other fungal PGs from postharvest fungal plant pathogens, i.e., Phomopsis cucurbitae, Botrytis cinerea, and P. italicum $(3,13,27)$. The PG produced by $P$. expansum during postharvest decay of pear fruit is larger than the $34 \mathrm{kDa} P G$ that was isolated and characterized from $P$. expansum-decayed apple fruit (26). The pIs of the two enzymes differ ( 7.8 versus 8.1 ), although both values are comparable to PGs from other fungi (15). The optimal $\mathrm{pH}$ for PG activity is also different (4.5 in pear versus 5.5 in apple). However, both values are within the range of $\mathrm{pH}$ optima for various fungal PGs $(1,14,18,24)$.

Biochemical properties such as thermolability, lack of glycosyl moieties, and activity at low temperature are shared among various fungal PGs including those produced by $P$. expansum in pear and apple fruit. Thermolability is a common feature of enzymes as high temperatures disrupt higher order structures that are maintained by hydrophobic interactions, hydrogen bonding and disulphide bridges. The purified PG from $P$. expansumdecayed pear fruit was active at temperatures from 0 to $50^{\circ} \mathrm{C}$. Activity of the PG over a broad temperature range gives the fungus the ability to macerate tissue and cause decay during cold storage, in the field in storage bins, or on grocery store shelves. Jurick et al. (11) showed that the purified PG from $P$. solitum was active at temperatures as low as $2^{\circ} \mathrm{C}$, which substantiates our findings that PGs from another Penicillium species have detectable enzymatic activity at low temperatures. The lack of glycosylation was demonstrated for both $P$. expansum PGs. However, a number of PGs from various fungal species (Saccharomyces cereviseae, Aspergillus kawachii, and Colletotrichum acutatum), have been shown to be glycosylated which seems to be the most common form of posttranslational modification for this class of hydrolytic enzymes (15). Thus, the difference in molecular mass between the two P. expansum PGs isolated from decayed pear and apple fruit may result from other forms of posttranslational modifications (e.g., myristolation, stearoylation, and geranylgeranlation, etc.), alternate splicing of the same gene, or different
A
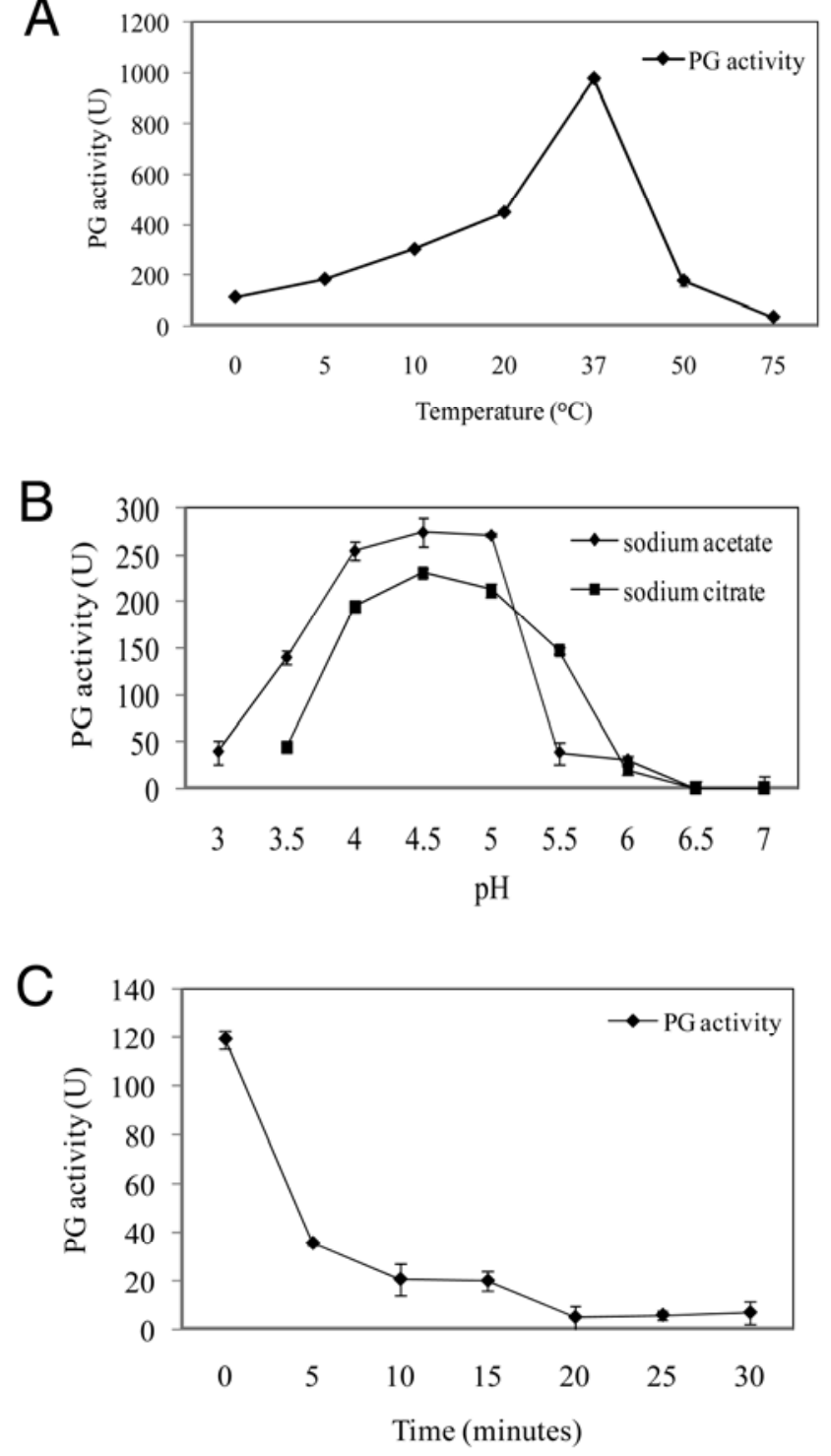

Fig. 5. A, Activity profile of purified polygalacturonase produced by Penicillium expansum in 'Anjou' pear fruit at various temperatures. B, Activity profile of purified polygalacturonase produced by $P$. expansum in decayed 'Anjou' pear fruit at different pHs. C, Activity profile of purified polygalacturonase produced by $P$. expansum in decayed 'Anjou' pear fruit following incubation at $100^{\circ} \mathrm{C}$ for different periods of time. Each data point represents the mean of three replicates with bars representing standard deviation of the means. All experiments were repeated and data from a representative experiment is shown.

PG genes encoding two distinct polypeptides. The latter possibility is in accord with the earlier observation that $P$. expansum produces at least five PG isozymes in culture (C. L. Yao, unpublished data).

The purified PG hydrolyzed sodium polypectate in a mixed manner exhibiting both endo and exo-activity. PG was unable to hydrolyze digalacturonic acid but cleaved the trimer into a monomer and dimer. This result shows that the enzyme requires a minimum length of three galacturonic acid residues for enzymatic cleavage. Mixed PG activity has also been reported for other purified PGs from the various fungal plant pathogens $P$. cucurbitae and $P$. expansum $(26,27)$. However, the PG produced by $P$. expansum during apple fruit decay produced monomers, dimers, and trimers of galacturonic acid after $24 \mathrm{~h}$, whereas the PG produced by the same fungus during pear decay produced monomeric, dimeric, trimeric, and oligomeric forms of galacturonic acid. 


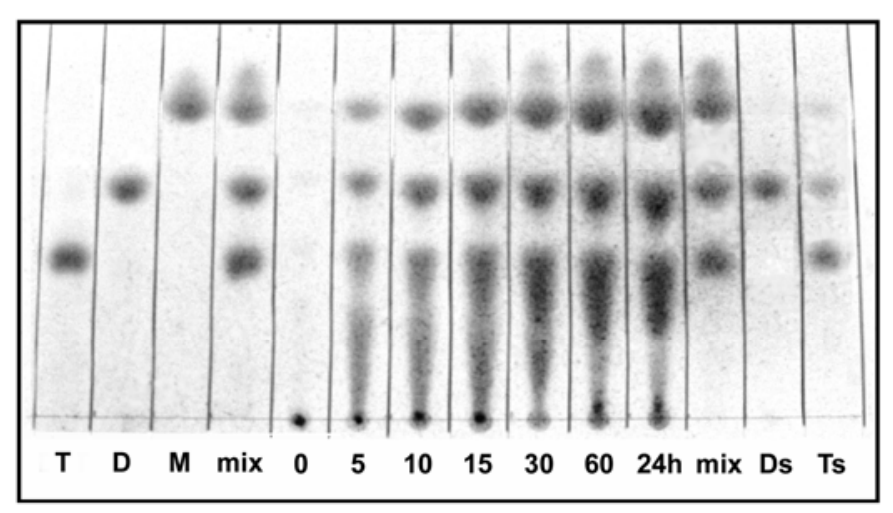

Fig. 6. Thin-layer chromatography of hydrolysis products from purified polygalacturonase produced by Penicillium expansum in decayed 'Anjou' pear fruit with different substrates. Lanes 1 through 4, trimer, dimer, monomer and a mix of standard galacturonic acid, respectively; lanes 5 through 11, hydrolysis products of sodium polypectate after incubation with $6 \mathrm{U}$ of purified polygalacturonase enzyme for $0,5,10,15,30$, and $60 \mathrm{~min}$ and $24 \mathrm{~h}$, respectively; lane 12, a mixture of monomer, dimer and trimer galacturonic acid standards; lane 13, hydrolysis products of digalacturonic acid for $24 \mathrm{~h}$; and lane 14, hydrolysis products of trigalacturonic acid for $24 \mathrm{~h}$.

An approximately $30 \%$ reduction in mass resulted when pear tissue plugs were incubated with native $P$. expansum $\mathrm{PG}$ obtained from decayed pear fruit. The reduction in mass indicates the ability of the purified PG to degrade pear fruit tissue in vitro and substantiates the role of this enzyme in postharvest decay of pear by $P$. expansum. Interestingly, a $30 \%$ reduction in mass of muskmelon fruit plugs resulted from incubation with a purified PG from Phomopsis cucurbitae in vitro which is consistent with data presented in this work (27). The authors concluded that PG may be involved in Phomopsis fruit rot of muskmelon based on the ability of the purified enzyme to macerate muskmelon fruit tissue in vitro. In contrast, only an $\approx 17 \%$ reduction in mass of fruit tissue occurred when the native PG from decayed pear fruit was incubated with apple fruit tissue. The different PG enzymes secreted by the same pathogen on different hosts may offer a "fitness" advantage, by expression of host specific enzymes that maximize degradation of the tissue and colonization. This assertion is further supported by the results from tests where the purified PG produced higher levels $(\approx 5.1$-fold increase) of soluble polyuronides in vitro when incubated with pear fruit tissue compared to increase ( $\approx 1.8$-fold) in buffer with apple fruit tissue. Residual levels of soluble polyuronides detected in the buffer only treatments may have been due to host-derived PGs that were active during the incubation period or may have resulted from nonenzymatic activity as they may have leached out into the buffer from damaged and or dead cells when plugs were cut from intact fruit.

Results from the activity assays indicate that the PG purified from $P$. expansum-decayed pear fruit is of fungal origin. This conclusion is supported by the lack of detectable PG activity from either wounded or intact pear fruit tissue in the plate assay with the $90 \%$ ammonium sulfate pellets, and a clear zone of activity on plates with the $90 \%$ ammonium sulfate pellet from the $P$. expansum-decayed pear fruit. Also, no PG activity in healthy intact or wounded pear fruit was detectable in crude extracts or ammonium sulfate fractions (40 and 90\% supernatant and pellets) using the PG plate activity assay or the quantitative reducing sugar assay (data not shown). Unfortunately, attempts to obtain N-terminal sequence data (Edman degradation method) from the purified PG produced by $P$. expansum during pear fruit decay were unsuccessful as it was determined that the $\mathrm{N}$ terminus was blocked.

This is the first report detailing the isolation, purification and biochemical characterization of PG from $P$. expansum-decayed pear tissue, also showing for the first time that the same pathogen
A

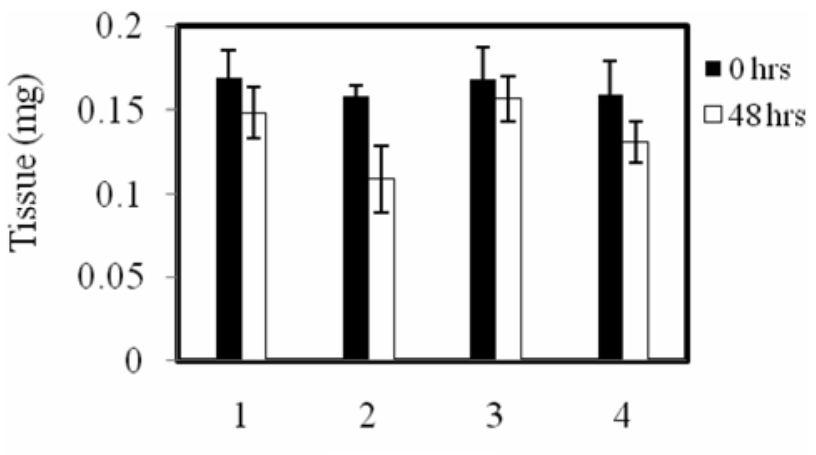

Treatment

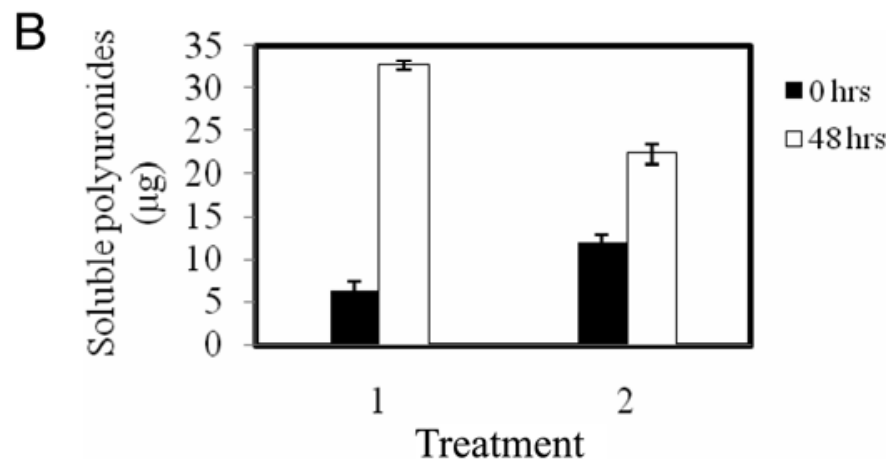

Fig. 7. A, Fresh weight changes of pear and apple tissue plugs after different treatments. Treatment 1 , buffer alone with pear tissue; treatment 2, polygalacturonase purified from decayed pear in buffer with pear tissue; treatment 3 , buffer alone with apple tissue; and treatment 4 , native polygalacturonase in buffer with apple tissue. B, Total soluble polyuronides liberated in $100 \mathrm{mM}$ sodium acetate buffer $(\mathrm{pH} 4.5)$ from pear and apple tissue in vitro. Treatment 1 , pear tissue with native polygalacturonase; and treatment 2, native polygalacturonase in buffer with apple tissue. All experiments were repeated and the results from a representative test are shown.

on a different host secretes a different PG enzyme. Moreover, this work also provides a foundation for molecular biological studies of PG in P. expansum-pear fruit interactions. Elucidation of the role of PG by molecular cloning and functional analysis will provide further insight into the mechanisms of invasion and colonization by this pathogen, and will lead to development of more specific and effective control strategies against postharvest pathogens.

\section{ACKNOWLEDGMENTS}

We acknowledge the technical contributions of J. Norman Livsey for gel filtration and cation exchange chromatography. This work was supported by the USDA project no. 1275-42430-008-00D. Mention of trade names or commercial products in the publication is solely for the purpose of providing specific information and does not imply recommendation or endorsement by the U.S. Department of Agriculture.

\section{LITERATURE CITED}

1. Barmore, C. R., and Brown, G. E. 1981. Polygalacturonase from citrus fruit infected with Penicillium italicum. Phytopathology 71:328-331.

2. Bateman, D. F., and Bashman, H. G. 1976. Degradation of plant cell walls and membranes by microbial enzymes. Encycl. Plant Physiol. New. Ser. 4:316-355

3. Bateman, D. F., and Miller, R. L. 1966. Pectic enzymes in tissue degradation. Annu. Rev. Phytopathol. 4:119-146.

4. Blumenkrantz, N., and Asboe-Hansen, G. 1973. New method of quantitative determination of uronic acids. Anal. Biochem. 54:484-489.

5. Conway, W. S. 1982. Effect of postharvest calcium treatment on decay of Golden Delicious apples. Plant Dis. 66:402-403.

6. Cooper, R. M. 1983. The mechanisms and significance of enzymic degradation of host cell walls by parasites. Pages 101-135 in: Biochemi- 
cal Plant Pathology. J. A. Callow, ed. John Wiley \& Sons, New York.

7. Errampalli, D. 2004. Effect of fludioxonil on germination and growth of Penicillium expansum and decay in apple cvs. Empire and Gala. Crop Prot. 23:811-817.

8. Have, A. T., Mulder, W., Visser, J., and van Kan, J. A. L. 1998. The Endopolygalacturonase gene Bcpg1 for full virulence of Botrytis cinerea. Mol. Plant-Microbe Interact. 11:1009-1016.

9. Hiwasa, K., Kinugasa, Y., Amano, S., Hashimoto, A., Nakano, R., Inaba, A., and Kubo, Y. 2003. Ethylene is required for both the initiation and progression of softening in pear (Pyrus communis L.) fruit. J. Exp. Bot. 54:771-779.

10. Jayani, R. S., Saxena, S., and Gupta, R. 2005. Microbial pectinolytic enzymes: A review. Proc. Biochem. 40:2931-2944.

11. Jurick, W. M., II, Vico, I., McEvoy, J. L., Whitaker, B. D., Janisiewicz, W., and Conway, W. S. 2009. Isolation, purification, and characterization of a polygalacturonase produced in Penicillium solitum-decayed 'Golden Delicious' apple fruit. Phytopathology 99:636-641.

12. Leammli, U. K. 1970. Cleavage of structural proteins during the assembly of the head of bacteriophage T4. Nature 227:680-685.

13. Marcus, L., and Schejter, A. 1983. Single step chromatographic purification of the endopolygalacturonases and pectinesterases of the fungus Botrytis cinerea Pers. Physiol. Plant Pathol. 22:1-13.

14. Mohamed, S. A., Farid, N. M., Hossiny, E. N., and Bassuiny, R. I. 2006. Biochemical characterization of an extracellular polygalacturonase from Trichoderma harzianum. J. Biotechnol. 127:54-64.

15. Niture, S. K. 2008. Comparative biochemical and structural characterization of fungal polygalacturonases. Biologia 63:1-19.

16. Ogawa, J. M., and English, H. 1991. Diseases of Temperate Zone Tree Fruit and Nut Crops. University of California, Division of Agriculture and Natural Resources, Oakland, CA.

17. Pilnik, W., and Voragen, A. G. J. 1991.The significance of endogenous and exogenous pectic enzyme in fruit and vegetable processing. Pages 330-336 in: Food Enzymology. P. F. Fox, ed. Elsevier Science Publishers, Amsterdam.

18. Rao, M. N., Kembhavi, A. A., and Pant, A. 1996. Implication of trypto- phan and histidine in the active site of endo-polygalacturonase from Aspergillus ustus: Elucidation of the reaction mechanism. Biochim. Biophys. Acta 1296:167-173.

19. Rosenberger, D. A. 1990. Blue mold. Pages 54-55 in: Compendium of Apple and Pear Diseases. A. L. Jones and H. S. Aldwinkle, eds. The American Phytopathological Society, St. Paul, MN.

20. Saad, N., Briand, M., Gardarin, C., Briand, Y., and Michaud, P. 2007. Production, purification, and characterization of an endopolygalacturonase from Mucor rouxii NRRL 1894. Enzyme Microbiol. Technol. 41:800-805.

21. Sanderson, P. G., and Spotts, R. A. 1995. Postharvest decay of winter pear and apple fruit caused by species of Penicillium. Phytopathology 85:103110.

22. Sekine, D., Munemura, I., Go, M., Mitsuhashi, W., Toyomasu, T., and Murayama, H. 2006. Cloning of cDNA's encoding cell-wall hydrolases from pear (Pyrus communis) fruit and their involvement in fruit softening and development of melting texture. Physiol. Plant 126:163-174.

23. Shieh, M. T., Brown, R. L., Whitehead, M. P., Cary, J. W., Cotty, P. J., Cleveland, T. E., and Dean, R. A. 1997. Molecular genetic evidence for the involvement of a specific polygalacturonase, $\mathrm{P} 2 \mathrm{c}$, in the invasion and spread of Aspergillus flavus in cotton bolls. Appl. Environ. Microbiol. 63:3548-3552

24. Singh, S. A., and AppuRao, A. G. 1989. A simple fractionation protocol for and a comprehensive study of the molecular properties of two major endopolygalacturonases from Aspergillus niger. Biotechnol. Appl. Biochem. 35:115-123.

25. Walton, J. D. 1994. Deconstructing the cell wall. Plant Physiol. 104:11131118 .

26. Yao, C., Conway, W. S., and Sams, C. E. 1996. Purification and characterization of a polygalacturonase produced by Penicillium expansum in apple fruit. Phytopathology 86:1160-1166.

27. Zhang, J., Bruton, B. D., and Biles, C. L. 1999. Purification and characterization of a prominent polygalacturonase isozyme produced by Phomopsis cucurbitae in decayed muskmelon fruit. Mycol. Res. 103:21-27. 